\title{
真空浸炭における雰囲気制御の実際
}

\author{
河 田 一 喜*1

\section{Atmosphere Control during Low-Pressure Carburizing} \\ Kazuki KAWATA*1 \\ *1President, Oriental Engineering Co., Ltd., 2-8-49 Yoshinodai, Kawagoe-shi, Saitama 350-0833, Japan
}

(Received April 11, 2016, Accepted July 4, 2016)

\begin{abstract}
Atmosphere control during low-pressure carburizing is important from a quality assurance viewpoint. We have developed a lowpressure carburizing furnace that can be used for mass production, which has an atmosphere control system comprising a thermal conductivity hydrogen sensor and an oxygen sensor.

The hydrogen sensor is used for providing an atmosphere control necessary for carrying out both low-pressure carburizing and carbonitriding processes. The oxygen sensor detects air leaks and sooting in the furnace. In this paper, we demonstrate that when the atmosphere during the low-pressure carburizing and carbonitriding processes is controlled using the hydrogen sensor, the amount of carbon and nitrogen infiltrated into the steel parts can be controlled, even if the parameters such as the flow rate of gases, temperature, and the surface area of the parts change.
\end{abstract}

\section{1. はじめに}

浸炭とは，低炭素鋼を $900 \sim 950^{\circ} \mathrm{C}$ 程度に加熱し，鋼表面 に炭素を浸透, 拡散させ表面層のみを高炭素にして焼入れ硬 化させる表面硬化処理法である．表面層は高炭素（約0.8\%） の硬いマルテンサイト組織を生成し, その内部は軟らかく勒 性に富んだ組織が得られるため, 耐摩耗性や耐疲労性に優れ た材料を作ることができる. そのため, 浸炭処理は自動車部 品, 建設機械部品等の各種の機械部品に広く適用されてい る. また, 炭素の久拡散させる浸炭に対して, 炭素以外に窒 素を同時に浸透, 拡散させることで焼入れ性を向上させる浸 炭窒化処理がある. 浸炭窒化処理は焼入れ性の悪いSPCC (冷延圧延鋼板), SUM24L（硫黄複合快削鋼）などの表面 硬化, 疲労強度の改善に適用されている. 浸炭窒化処理は, 歯車の耐ピッチング性を向上させる目的で SCr420や SCM415にも適用されている.

真空浸炭は, ガス浸炭に比べて環境に優しい, 自動化しや すい, 粒界酸化がない, 浸炭速度が大きい, 深穴品に浸炭で きるなどの特徵により国内外において普及が進んできてい る1-3). しかしながら, 大気圧下で処理するガス浸炭と違っ て, 真空浸炭は減圧下で処理するため, 減圧状態の雾囲気を 分析制御する技術が確立できていなかった。 すなわち, 雾囲 気制御していないために処理の品質保証ができない, 鋭角部 にセメンタイトが生成しやすい, 鍛造肌部, 治具, トレーに 煤付着しやすいなど短所もある.

当社は熱伝導式水素センサと酸素センサにより真空浸炭処 理の雾囲気制御を可能とする技術を世界に先駆けて開発, 雾 囲気制御機能付き真空浸炭炉を量産化し ${ }^{4-12)}$, 日本, アメリ カ, ヨーロッパ，中国において真空浸炭の雲囲気制御技術に 関して特許も取得した. さらに, 当社では複数のガスの雾囲 気制御技術も開発した. 真空浸炭炉内や排気系に抢ける煤や

*1 オリエンタルエンヂニアリング株式会社（テ350-0833 埼玉県 川越市芳野台 2-8-49)
タール発生を防ぐためには炭素の浸透, 拡散に用いるアセチ レンガス以外に窒素ガスを真空浸炭炉に供給することが有効 となるためである、ただし, アセチレンガスと窒素ガスとい うような複数ガスの䨌囲気制御は難度が高くなる. 本稿で は，これらの技術を利用した真空浸炭における雾囲気制御の 概要と実際の䨌囲気制御技術について紹介する.

\section{2. 真空浸炭炉内のガス反応と制御}

真空浸炭する場合の炉内のガス反応と制御のモデル10)を Fig. 1 に示す.

アセチレンガス $\left(\mathrm{C}_{2} \mathrm{H}_{2}\right)$ は処理品に接触すると炭素 $(\mathrm{C})$ を処理品の中に浸透拡散させ, 水素 $\left(\mathrm{H}_{2}\right)$ を放出する. し たがって， $\mathrm{C}_{2} \mathrm{H}_{2}, \mathrm{C}, \mathrm{H}_{2}$ 濃度のいずれかを測定することで 処理品表面の炭素濃度を推定することが可能と考えられる. しかしながら現状では， $\mathrm{C}_{2} \mathrm{H}_{2}$ を連続分析できる安価な分析 計は無い. C に関しては, 鉄線を炉内に挿入して抢き, 直接 その鉄線を浸炭させ抵抗值等を測定することで炭素濃度を推 定する方法が考えられたが，この方法は繰り返し測定するこ とが困難であり, フィードバック制御に使うことができず装 置化はされていない。 また, 炬内のガスを炉外の分析計に引 き込みガスを分析する方法も考えられたが, 分析応答速度が

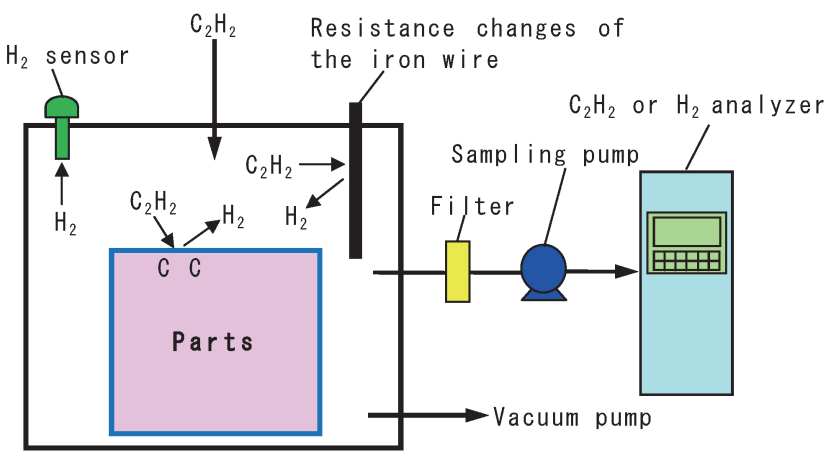

Fig. 1 (Color online) Atmosphere control and gas reaction in the low-pressure carburizing furnace ${ }^{10}$. 
遅い, サンプリング径路のメンテナンスが必要になるなどの 理由でやはり装置化はされていない。このような問題に対し て当社では, 熱伝導度を利用した水素センサを開発した。本 センサは減圧下でも作動し, 分析応答速度も速く, メンテナ ンスフリーである. 熱伝導度を利用した水素センサについて は 4 節で詳細に説明する.

ここで真空浸炭の表面反応について考える．例えば $\mathrm{C}_{2} \mathrm{H}_{2}$ を使って浸炭する場合, ガスの炬内滞留時間が短く, 正反応 が支配的であるため，制御が困難であるというのが世界的に も一般的な見解であった。しかし, 減圧状態の炉内に $\mathrm{C}_{2} \mathrm{H}_{2}$ が多く残っていれば浸炭が強く, 逆に $\mathrm{H}_{2}$ が多いと浸炭が弱 いという事実がある10)。 また，真空浸炭窒化の窒化サイク ルに颃いて $\mathrm{NH}_{3}$ を使って窒化する場合, 減圧状態の炉内に $\mathrm{NH}_{3}$ が多く残っていれば窒化が強く, 逆に $\mathrm{H}_{2}$ が多いと窒化 が弱いという事実がある9

このような浸炭や窒化の強さ, すなわちポテンシャルが存 在するということは，たとえ減圧状態の正反応が支配的な反 応であっても, ガスの分解度を制御することによってそのポ テンシャルを制御可能であることを示している.

\section{3. 浸炭ポテンシャルと窒化ポテンシャル}

浸炭ガスとしてたとえばアセチレンガス $\left(\mathrm{C}_{2} \mathrm{H}_{2}\right)$ を使用 した場合に, 減圧下の加熱室内では主に次のようなガス反応 が起こる.

$$
\mathrm{C}_{2} \mathrm{H}_{2} \rightarrow 2[\mathrm{C}]+\mathrm{H}_{2}
$$

式(1)より浸炭ポテンシャル $\mathrm{K}_{\mathrm{C}}$ は以下のように定義する.

$$
\mathrm{K}_{\mathrm{C}}=\sqrt{\mathrm{P}_{\mathrm{C}_{2} \mathrm{H}_{2}} / \mathrm{P}_{\mathrm{H}_{2}}}
$$

$\left(\mathrm{P}_{\mathrm{C}_{2} \mathrm{H}_{2}}, \mathrm{P}_{\mathrm{H}_{2}}: \mathrm{C}_{2} \mathrm{H}_{2}, \mathrm{H}_{2}\right.$ の分圧 $)$

また，アンモニアガス $\left(\mathrm{NH}_{3}\right)$ を使って窒化する場合には， 減圧下の加熱室内では主に次のようなガス反応が起こる.

$$
\mathrm{NH}_{3} \rightarrow[\mathrm{N}]+3 / 2 \mathrm{H}_{2}
$$

式(2)より窒化ポテンシャル $\mathrm{K}_{\mathrm{N}}$ は以下のように定義する.

$$
\mathrm{K}_{\mathrm{N}}=\mathrm{P}_{\mathrm{NH}_{3}} / \mathrm{P}_{\mathrm{H}_{2}}^{3 / 2}
$$

$\left(\mathrm{P}_{\mathrm{NH}_{3}}, \mathrm{P}_{\mathrm{H}_{2}}: \mathrm{NH}_{3}, \mathrm{H}_{2}\right.$ の分圧 $)$

(2), (4) 式で定義される浸炭ポテンシャル $\mathrm{K}_{\mathrm{C}}$, 窒化ポテ ンシャル $\mathrm{K}_{\mathrm{N}}$ は $\mathrm{C}_{2} \mathrm{H}_{2}, \mathrm{NH}_{3}$ 濃度により变わり雾囲気の浸炭 能力, 窒化能力を表す指数として利用される13).

以上のように，炉内の $\mathrm{H}_{2}$ 濃度を測定できれば，式 (1)お よび式(3)より $\mathrm{C}_{2} \mathrm{H}_{2}$ や $\mathrm{NH}_{3}$ の分圧を算出することができ, $\mathrm{K}_{\mathrm{C}}$ や $\mathrm{K}_{\mathrm{N}}$ を求めることができる.ただ, 減圧状態における $\mathrm{K}_{\mathrm{C}}$ や $\mathrm{K}_{\mathrm{N}}$ の数值と実際の処理品表面炭素濃度との関係を示 すよりは, 直接 $\mathrm{H}_{2}$ 濃度と処理品表面炭素濃度との関係をグ ラフ化して示すほうがわかりやすいため, 以下ではそのよう な表記で示した.

\section{4. 熱伝導式水素センサの原理}

熱伝導式水素センサは標準ガスと測定ガスとの熱伝導度の 違いを利用したものである. Fig. 2 に熱伝導式水素センサ
の原理図 ${ }^{10)}$ を示す。あらかじめ電気的に加熱した白金線コ イルに測定ガスが触れると，その気体の熱伝導によって熱が 奪われ，白金線コイルの温度が変化する．この变化はガスの 分圧に比例するので，白金線の抵抗值変化をホイートストン ブリッジ回路の偏差電圧として取り出し測定ガス濃度を算出 するのがその原理である．Fig. 3 に各種ガスの熱伝導度を 示す10). この図より $\mathrm{H}_{2}$ が最も熱伝導度が高いことがわかる.

Fig. 4 に当社で製造した各種熱伝導式水素センサ11)を示 す．この熱伝導式水素センサには，大気圧下の処理であるガ 久軟窒化, ガス浸炭, ガス浸炭窒化, 浸窒焼入れ等に使用す

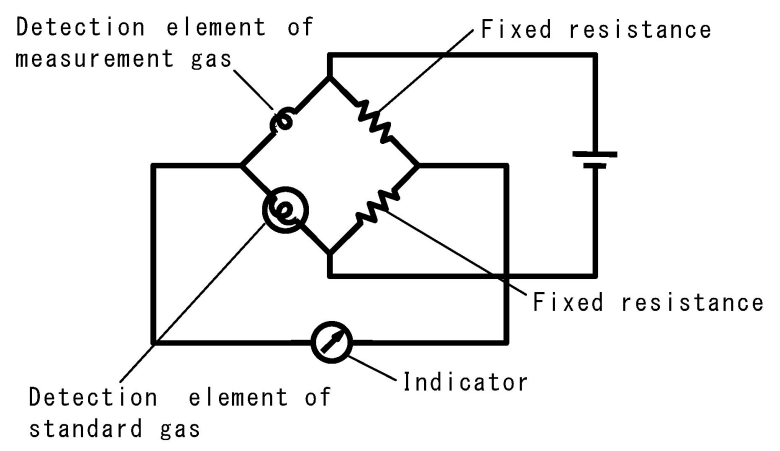

Fig. 2 Principle diagram of the thermal conductivity hydrogen sensor ${ }^{10)}$.

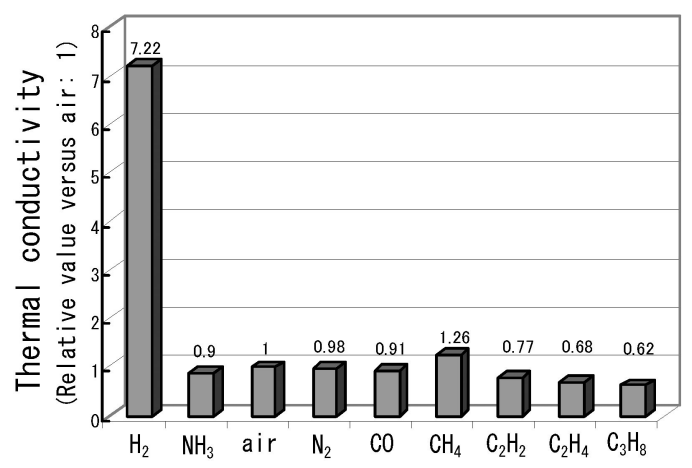

Fig. 3 Thermal conductivities of various gases ${ }^{10)}$.

\section{Low-pressure carburizing} (Standard)

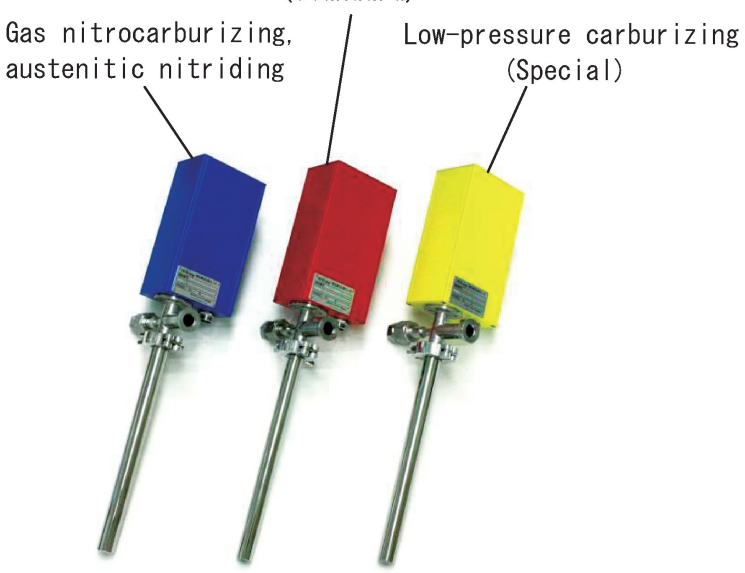

Fig. 4 (Color online) Appearance of various types of thermal conductivity hydrogen sensors ${ }^{11}$. 
る大気圧下で作動する青色の水素センサ, 真空浸炭, 真空浸 炭窒化処理に使用し $1,000 \mathrm{~Pa} \sim$ 大気圧で作動する赤色の水素 センサ, $100 \sim 1,000 \mathrm{~Pa}$ で作動する黄色の真空浸炭, 真空浸 炭窒化用水素センサの 3 種類のタイプがある.

\section{5. $\mathbf{H}_{2}$ 濃度と浸炭特性との関係}

浸炭ガスに $\mathrm{C}_{2} \mathrm{H}_{2}$ を使った場合に, 熱伝導式水素センサを 用いることで得られた $\mathrm{H}_{2}$ 濃度と浸炭特性との関係を以下に 説明する.な技, 以下の説明は, グロス処理重量 $600 \mathrm{~kg}$ の バッチタイプの量産型真空浸炭炉を使った結果によるもので ある. 浸炭温度, 圧力, 処理品表面積等の他の条件が一定の 場合, $\mathrm{C}_{2} \mathrm{H}_{2}$ 流量が少なくなると $\mathrm{C}_{2} \mathrm{H}_{2}$ ガスの高温での炉内 滞留時間が長くなり $\mathrm{C}_{2} \mathrm{H}_{2}$ ガスが分解しやすくなる. そのた め, 炉内 $\mathrm{H}_{2}$ 濃度が高くなる。逆に, $\mathrm{C}_{2} \mathrm{H}_{2}$ 流量が多くなる と $\mathrm{C}_{2} \mathrm{H}_{2}$ ガスの高温での炉内滞留時間が短くなり $\mathrm{C}_{2} \mathrm{H}_{2}$ ガス が分解しづらくなる. そのため, 炉内 $\mathrm{H}_{2}$ 濃度が低くなる.

Fig. 5 に圧力および処理品表面積が一定の状態で, 炉内 に導入する $\mathrm{C}_{2} \mathrm{H}_{2}$ 流量の久を变化させた場合の炉内 $\mathrm{H}_{2}$ 濃度 と細穴内面浸炭性の関係を示す ${ }^{10)}$. これは炉内 $\mathrm{H}_{2}$ 濃度の変 化が細穴内面浸炭性に与える影響を調査する目的で行ったも のである. Fig. 5 において carburizing rate（\%）は, 試験 片外面の浸炭深さに対する細穴内面浸炭深さの割合を示して おり，100\%であれば細穴内面部も外面と同じ浸炭深さが得 られていることを表している. 浸炭温度が $930^{\circ} \mathrm{C}$ 抢よ゙ 1050 ${ }^{\circ} \mathrm{C}$ とに, 炉内 $\mathrm{H}_{2}$ 濃度が増加するほど細穴内面浸炭性が悪 くなっている.この理由は, $\mathrm{H}_{2}$ 濃度が増加し, 逆に浸炭ガ スの $\mathrm{C}_{2} \mathrm{H}_{2}$ 濃度が減少することにより浸炭ポテンシャルが低 くなっているためである. また, 同じ $\mathrm{H}_{2}$ 濃度であっても細 穴内面浸炭性は $930^{\circ} \mathrm{C}$ より $1050^{\circ} \mathrm{C}$ と浸炭温度が高いほど悪 くなっている.

以上のように, $\mathrm{C}_{2} \mathrm{H}_{2}$ さえ使えばノズルのような細穴内面 浸炭性に優れるということではなく, 浸炭温度に応じた適切 な炉内 $\mathrm{H}_{2}$ 濃度に䨌囲気を制御することが細穴内面浸炭性に とって重要であるということがわかる.

炉内 $\mathrm{H}_{2}$ 濃度は浸炭特性だけではなく, 処理品表面積や表

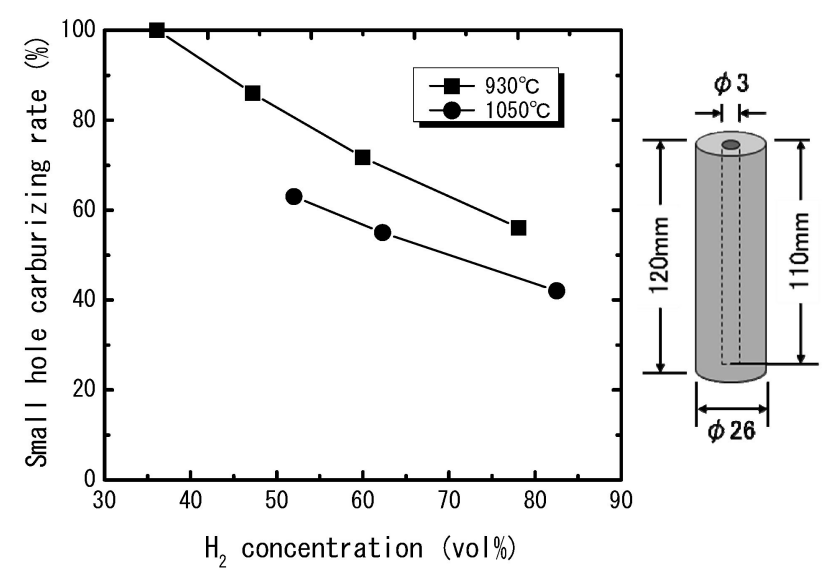

Fig. 5 Relation between the small hole carburizing characteristics and hydrogen concentrations ${ }^{10)}$ (Carburizing gas: $\mathrm{C}_{2} \mathrm{H}_{2}$, Pressure: $1067 \mathrm{~Pa}$, Surface area of parts: $10.4 \mathrm{~m}^{2}$, TP: SCM415).
面炭素濃度とも密接な関係がある. 適切な浸炭処理を行うた めにこの関係を利用している. Fig. 6 に処理品表面積と $\mathrm{H}_{2}$ 濃度との関係 ${ }^{12)}$ を示す. 処理品表面積が増加するほど $\mathrm{H}_{2}$ 濃 度が増加している.これは, 処理品表面積が増加するほど炉 内に導入した $\mathrm{C}_{2} \mathrm{H}_{2}$ の反応面積が増加し, より多くの $\mathrm{C}_{2} \mathrm{H}_{2}$ が分解したことを示している. このように, 炬内 $\mathrm{H}_{2}$ 濃度と 処理品表面積とは相関関係があることがわかる，すなわち， あらかじめ表面積が測定できるダミ一品で検量線を作成して おけば, 実際の三次元立体の複雑形状をした部品の表面積を 瞬時に判断することができる. そのため, 処理品表面積に適 した添加 $\mathrm{C}_{2} \mathrm{H}_{2}$ 量を浸炭期の初期段階に決定することができ る.このことは, 真空浸炭の最大の欠点であった荷姿, 処理 品表面積により浸炭品質が安定しないという問題を解決でき たことになる．

Fig. 7 に浸炭温度, 圧力および処理品表面積が一定の状 態で, 炉内に導入する $\mathrm{C}_{2} \mathrm{H}_{2}$ 流量のみを変化させた場合の表 面炭素濃度と炬内 $\mathrm{H}_{2}$ 濃度との関係 ${ }^{10)}$ を示す。この図より $\mathrm{H}_{2}$ 濃度と表面炭素濃度とは密接な関係があることがわか る.したがって, 熱伝導式水素センサにより $\mathrm{H}_{2}$ 濃度を検知 すれば, ある浸炭時間のときに表面炭素濃度がどのような值

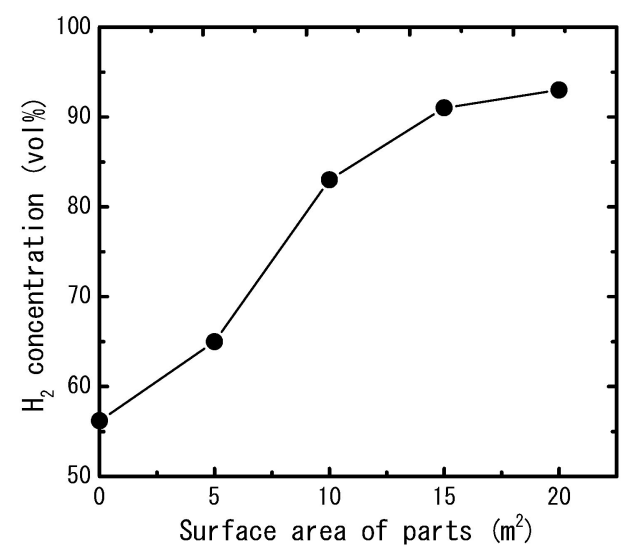

Fig. 6 Relation between the surface area of parts and hydrogen concentrations ${ }^{12)}$ (Temperature: $950^{\circ} \mathrm{C}$, Pressure: 1067 $\left.\mathrm{Pa}, \mathrm{C}_{2} \mathrm{H}_{2}: 30 \mathrm{~L} / \mathrm{min}\right)$.

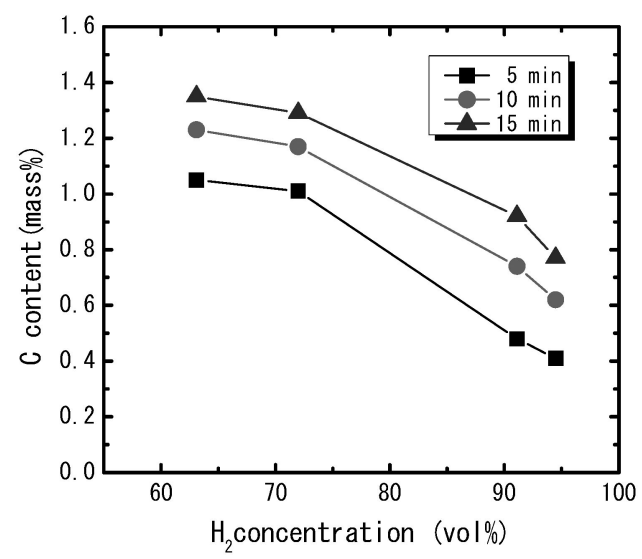

Fig. 7 Relation between the hydrogen concentration and surface carbon content ${ }^{10)}$ (Temperature: $950^{\circ} \mathrm{C}$, Pressure: 1067 $\mathrm{Pa}$, Surface area of parts: $10.4 \mathrm{~m}^{2}$, TP: SCM415). 
になるかを知ることができ，また炭素濃度の制御もできるこ とになる。

以上のような真空浸炭中の表面炭素濃度と $\mathrm{C}_{2} \mathrm{H}_{2}$ の分解挙 動 $\left(\mathrm{H}_{2}\right.$ 濃度）がわかれば, 水素センサにより浸炭時間の経 過とともに連続的に $\mathrm{C}_{2} \mathrm{H}_{2}$ の分解度 $\left(\mathrm{H}_{2}\right.$ 濃度) を適正な值 に制御することができ，スーティング（遊離した炭素が炉内 の䨌囲気中に浮遊し, 処理品, 炉内壁, 擋汼および搬送装置 などに付着する現象）や逆に炭素供給不足のない理想的な真 空浸炭処理が可能になる.

次に, 実プロセスにおける水素センサの挙動を説明する.

Fig. 8 に実際の真空浸炭処理ヒートパターンにおける各浸 炭サイクルの $\mathrm{H}_{2}$ 濃度の変化 ${ }^{10)}$ を示す. 浸炭 1 サイクルにお

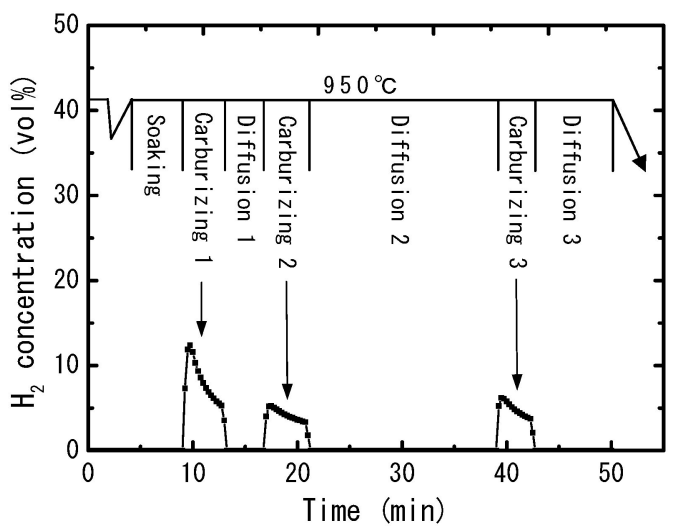

Fig. 8 Changes in the hydrogen concentrations for each carburizing cycle in the low-pressure carburizing heat pattern ${ }^{10)}$.

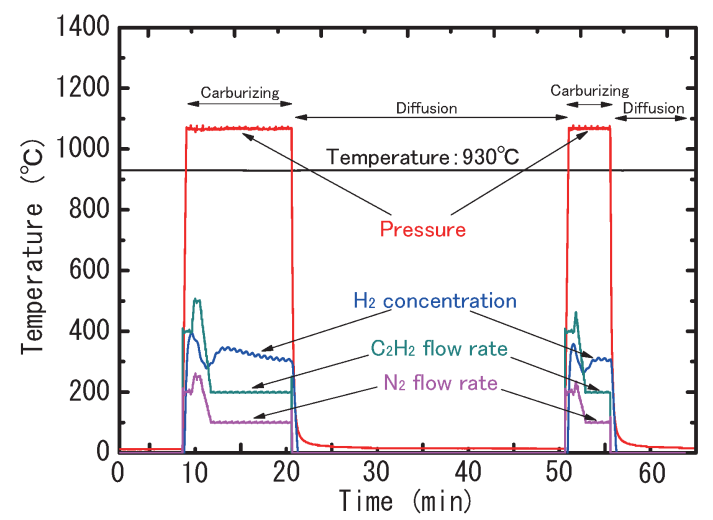

Fig. 9 (Color online) Chart indicating the actual atmosphere control during low-pressure carburizing ${ }^{11)}$ (Temperature: $950^{\circ} \mathrm{C}$, Pressure: $1067 \mathrm{~Pa}$, Mixed gas: $\mathrm{C}_{2} \mathrm{H}_{2}+\mathrm{N}_{2}$ ).
いては, 処理品表面炭素濃度は低いため $\mathrm{C}_{2} \mathrm{H}_{2}$ が多く分解し て処理品に炭素（C）を供給している．そのことは浸炭 1 サ イクルの初期の $\mathrm{H}_{2}$ 濃度が高いことよりわかる。拡散 1 にお いて処理品表面炭素は内部に拡散しているが，時間が短いた め十分に表面炭素濃度が下がっていないことが浸炭 2 サイ クルの $\mathrm{H}_{2}$ 濃度の推移でわかる.つぎに拡散 2 では拡散時間 を長く取ったため, 処理品表面炭素が内部に拡散し, 浸炭 3 サイクルの最初の $\mathrm{H}_{2}$ 濃度が浸炭 2 サイクルのそれより高く なっている. このように, 処理品の表面炭素濃度が真空浸炭 中の $\mathrm{C}_{2} \mathrm{H}_{2}$ の分解度に影響を与えており，そのことを熱伝導 式水素センサが敏感に捉えていることがわかる.

冒頭で述べたように真空浸炭炉内にアセチレンガス以外に 窒素ガスを導入して浸炭処理することでスーティングやター ル発生を抑制できることが知られている．Fig. 9 にアセチ レンガスと窒素ガスの 2 種類のガスを導入して雾囲気制御 しながら真空浸炭処理しているときの実際の記録チャー ト11)を示す。実際のプロセスでは, 品質管理のために制御 している炉内 $\mathrm{H}_{2}$ 濃度だけでなく炉内圧力, 炉内温度, 添加 $\mathrm{C}_{2} \mathrm{H}_{2}$ 流量, 添加 $\mathrm{N}_{2}$ 流量と全てのパラメータを記録しなが ら処理を行っている.

\section{6. 真空浸炭窒化における雾囲気制御}

真空浸炭窒化処理はガス浸炭窒化処理と違って，一般的に 浸炭処理と窒化処理をプラスする Fig. 10のようなヒートサ イクル9)で行う。これは, 処理品に炭素 (C) および窒素 （N）を有効に供給するための浸炭と窒化時の圧力がそれぞ れ異なっているためである.

真空浸炭と同様の量産型真空浸炭炉を使って，Fig. 10に 示したヒートサイクルで真空浸炭窒化処理を行った．この場 合, 窒化処理はアンモニアガス $\left(\mathrm{NH}_{3}\right)$ を使い, 処理温度, 処理時間, 圧力, $\mathrm{NH}_{3}$ 流量, 処理品表面積を変化させて行 った. Fig. $11 に 820^{\circ} \mathrm{Cで}$ 圧力 : $8000 \mathrm{~Pa}$, 処理品表面積 : 5 $\mathrm{m}^{2}$ 一定で $\mathrm{NH}_{3}$ 流量だけを変化させた場合の表面窒素濃度と $\mathrm{H}_{2}$ 濃度の変化 ${ }^{9)}$ を示す. $\mathrm{NH}_{3}$ 流量が増加するほど SCM415 および $\mathrm{S} 10 \mathrm{C}$ ともに表面窒素濃度は高くなり，逆に $\mathrm{H}_{2}$ 濃度 は低くなっている。これは, $\mathrm{NH}_{3}$ 流量が増加すると, 炉内 の残留 $\mathrm{NH}_{3}$ 量が増加し, 逆に $\mathrm{H}_{2}$ 量は減少するため窒化ポ テンシャルが上がるためである。試験片の材質に関しては, $\mathrm{NH}_{3}$ 流量に関わらず SCM415の方が S10C に比べて表面窒 素濃度は高くなっている。

Fig. 12 に $820^{\circ} \mathrm{C}$ で圧力 : $8000 \mathrm{~Pa}, \mathrm{NH}_{3}$ 流量 : $80 \mathrm{~L} / \mathrm{min}$

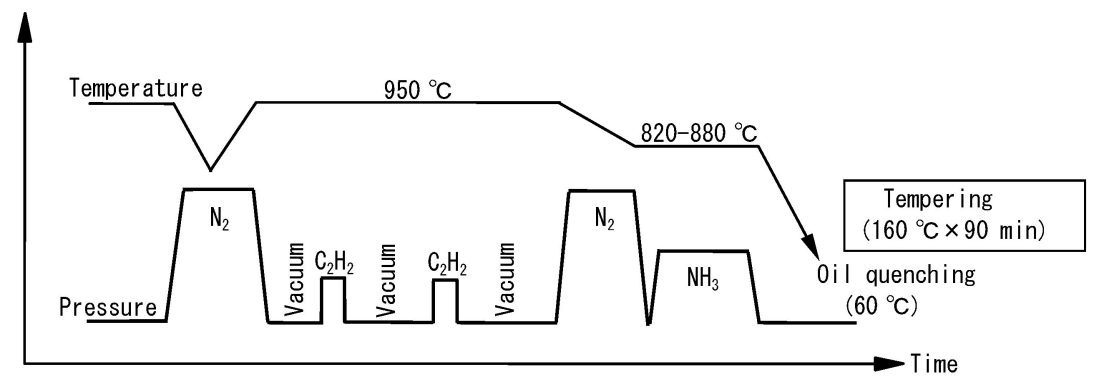

Fig. 10 Low-pressure carbonitriding cycle ${ }^{9)}$. 
一定で処理品表面積だけを変化させた場合の表面窒素濃度と $\mathrm{H}_{2}$ 濃度の変化 ${ }^{9)}$ を示す。処理品表面積が増加するほど表面 窒素濃度は低くなり，逆に $\mathrm{H}_{2}$ 濃度は高くなっている。これ は，表面積が増加すると $\mathrm{NH}_{3}$ との反応面積が増えることに より炉内残留 $\mathrm{NH}_{3}$ 量が減少し, 逆に $\mathrm{H}_{2}$ 量は増加すること によって窒化ポテンシャルが下がるためである。このような 表面積と $\mathrm{H}_{2}$ 濃度との関係を知れば, 表面積が変化しても $\mathrm{H}_{2}$ 濃度が一定になるように $\mathrm{NH}_{3}$ 流量をフィードバック制御 することで処理品表面窒素濃度を一定にすることができる.

Fig. 13に圧力 : $8000 \mathrm{~Pa}, \mathrm{NH}_{3}$ 流量 : $80 \mathrm{~L} / \mathrm{min}$, 処理品

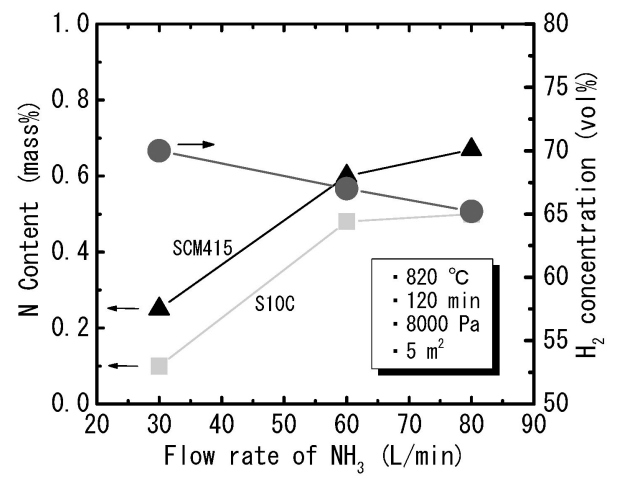

Fig. 11 Surface nitrogen content of the specimens and hydrogen concentration in the furnace as a function of $\mathrm{NH}_{3}$ flow rate $^{9)}$.

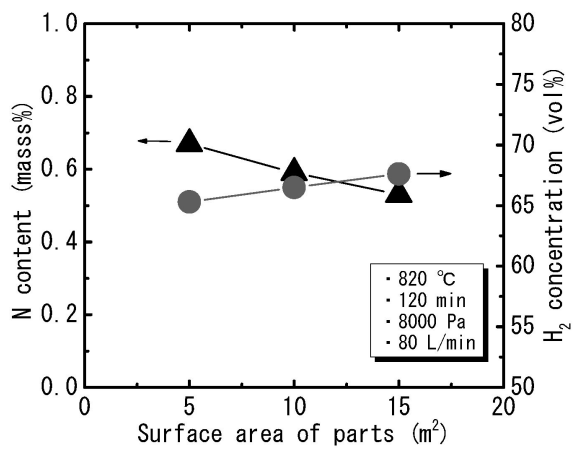

Fig. 12 Surface nitrogen content of the SCM415 specimens and hydrogen concentration in the furnace as a function of surface area of the parts ${ }^{9)}$.

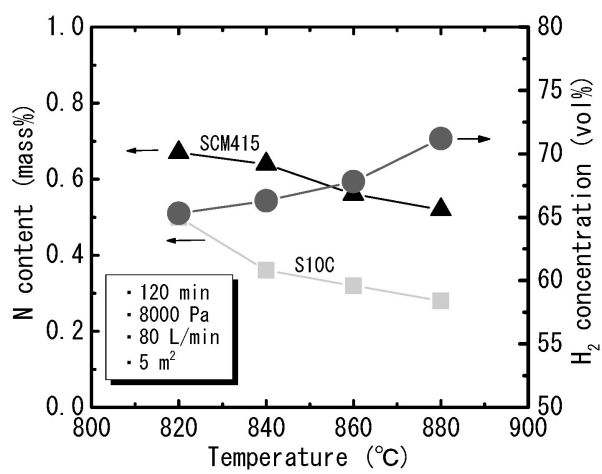

Fig. 13 Surface nitrogen content of the specimens and hydrogen concentration in the furnace as a function of nitriding temperature ${ }^{9)}$.
表面積 : $5 \mathrm{~m}^{2}$ 一定で処理品温度だけを変化させた場合の表 面窒素濃度と $\mathrm{H}_{2}$ 濃度の変化 ${ }^{9)}$ を示す. 処理温度が高くなる ほど表面窒素濃度は低くなり，逆に $\mathrm{H}_{2}$ 濃度は高くなってい る。これは, 処理温度が高くなると, 炉内残留 $\mathrm{NH}_{3}$ 量が減 少し, 逆に $\mathrm{H}_{2}$ 量は増加することによって窒化ポテンシャル が下がるためである。試験片の材質に関しては，処理温度に 関わらず SCM415の方が S10C に比べて表面窒素濃度は高 くなっている.

以上のように炉体に直接装着された熱伝導式水素センサを 用いて $\mathrm{H}_{2}$ 濃度を分析することにより，真空浸炭窒化処理に ついても浸炭サイクルに拉いては浸炭ポテンシャルを，窒化 サイクルに拈いては窒化ポテンシャルをそれぞれ制御するこ とで処理の品質保証が可能となる.

\section{7. 量産処理における䨌囲気制御の実際}

真空浸炭炉内の水素濃度を水素センサにより迅速に分析制 御することにより安定した品質を再現性よく得られるため, 多くの雾囲気制御付き真空浸炭炉の販売実績ができた。ま た，当社の加工部門においても $600 \mathrm{~kg}$ タイプの雲囲気制御 付き真空浸炭炉を合計 3 台導入し，量産受託処理加工を行 っている. 加工部門で行っている処理は，真空浸炭処理を指 定された自動車部品がほとんどで, 部品メーカーと設計段階 から共同で立ち上げた製品が多くある．Fig. 14に当社加工 部門で稼働している $600 \mathrm{~kg}$ タイプの量産型䨌囲気制御付き 真空浸炭炉の外観 11 を示す.

また，低い圧力範囲でも作動できる水素センサの開発も行 った：これにより，使用圧力範囲が異なる他社製真空浸炭炉 への水素センサ制御システムの販売実績も増えてきている. その一例として低い圧力で作動するタイプの水素センサで, 処理品表面積の違いによるアセチレンガスの分解挙動 $\left(\mathrm{H}_{2}\right.$ 濃度）を正確に捉えた例11)を Fig. 15に示す。

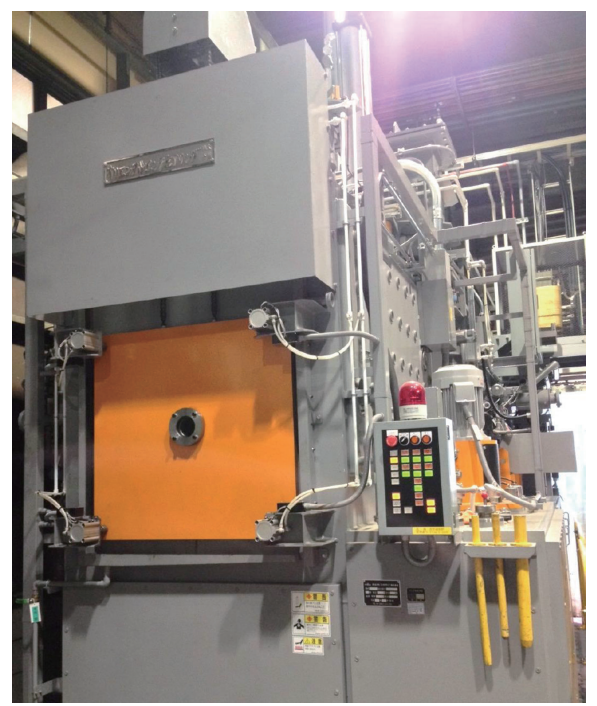

Fig. 14 (Color online) Low-pressure carburizing furnace with atmosphere control system ${ }^{11)}$ (processing gross weight: $600 \mathrm{~kg}$ ). 


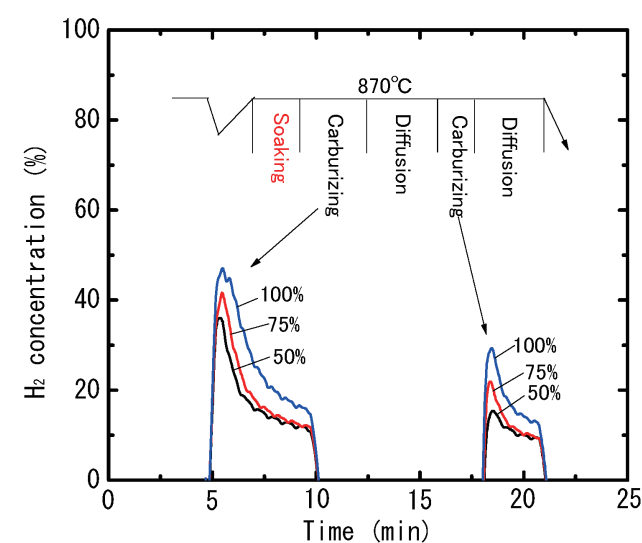

Fig. 15 (Color online) Relation between the surface area of parts and hydrogen concentration ${ }^{11)}$ (Carburizing gas: $\mathrm{C}_{2} \mathrm{H}_{2}$, Pressure: $300 \mathrm{~Pa}$ ).

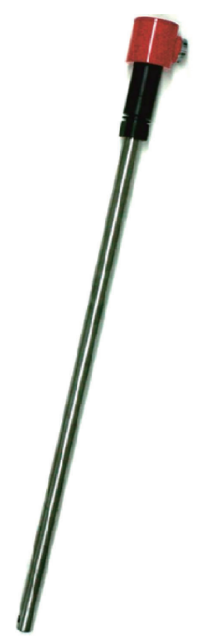

Fig. 16 (Color online) Oxygen sensor for low-pressure carburizing ${ }^{11}$.

\section{8. 最新雲囲気制御技術}

当社の真空浸炭における雾囲気制御技術のなかには，水素 センサだけでなく酸素センサによる雾囲気制御技術もある.
Fig. 16に，真空浸炭炬用に開発した酸素センサ11)を示す. 真空に耐えられる気密構造と炭化水素ガスの触媒作用を受け ない電極材料を採用したことが特徵である．前述の水素セン サで処理品が適切な表面炭素濃度になるように制御すると同 時に，この酸素センサで真空浸炭炉内の微量の酸化成分を制 御することで，真空浸炭の最大の欠点である鋭角部にセメン タイトが生成しやすいことに関してその生成をかなり抑制で きるようになった。 また，付随効果としてギア等の鍛造肌 部，治具，トレーへの煤付着を防止でき，真空浸炭技術の大 きな進歩を実現することができた。

\section{9. 結 言}

当社の真空浸炭に打ける雾囲気制御技術は 2000 年に開発 して以来, 常に性能向上に努めてきた. 水素センサと酸素セ ンサによる最適雾囲気制御技術が今後の真空浸炭の本格的な 普及に貢献できれば幸いである。

\section{〔文献〕}

1) M. Sugiyama, K. Ishikawa and H. Iwata: Adv. Mater. Process., 4 (1999) H29.

2) W. Gräfen and B. Edenhofer: Heat Treatment of Metals, 26 (1999) 79

3) M. Lohrmann, W. Gräfen, D. Herring and J. Greene: Heat Treatment of Metals, 29 (2002) 39.

4) K. Kawata: The Special Steel, 50 (2001) 24.

5) K. Kawata: Industrial Heating, 39 (2002) 37.

6) K. Kawata, S. Asai and T. Naito: Proceedings from the $1^{\text {st }}$ International Surface Engineering Congress and the $13^{\text {th }}$ IFHTSE Congress, Columbus, USA (2002) 68.

7) K. Kawata: Journal of the Japan Society for Heat Treatment, 44 (2004) 289.

8) K. Kawata: Machine Design, 48 (2005) 22.

9) K. Kawata, S. Asai: Proceedings of the $17^{\text {th }}$ IFHTSE Congress, Kobe, Japan (2008) 327.

10) K. Kawata: Journal of the Japan Society for Heat Treatment, 50 (2010) 601.

11) K. Kawata: Mechanical Surface Tech, 8 月号 (2015) 32.

12) K. Kawata: Nitriding, Carburizing and Plasma CVD (Nikkan Kogyo Shimbun, Tokyo, 2012) p.236.

13) H. Klümper-Westkamp: Proceedings of European Conference on Heat Treatment 2010, Aachen, Germany (2010) 39. 